\title{
Tendencies of Adapting Building Materials and Constructive Solutions to the Present Climate Changes
}

\author{
Draghici Gabriela, Filip Cosmin and Bizu Alexandru Nicolae
}

\begin{abstract}
The changes occurred on the climate are a reality that produces changes within the socio-economic environment. Climate change is largely due to greenhouse gas emissions generated by human, domestic and economic activities. In this climate, the constructive solutions of buildings must take into account climate changes and meet new requirements. In this context, building materials must improve and correspond to the new paradigm so as to fulfill their basic role, namely:

- creating an indoor climate corresponding to the hygienic-sanitary and thermal,

- comfort requirements in residential and socio-cultural buildings,

- ensuring the necessary indoor climate for carrying out economic activities reducing, as much as possible, the energy consumption for space heating.
\end{abstract}

Keywords - climate changes, constructive solutions, passive house, thermal insulation

\section{INTRODUCTION}

Climate change is a state that, first of all, we have all felt, due to the occurrence of extreme weather events. Researchers began to study these phenomena along with the changes produced in the habitats of fauna and flora and then it was studied by researchers and so the first conclusions were drawn.

It is already known that one of the main causes for climate change is the burning of fossil fuels - coal, natural gas, oil. By burning them, greenhouse gases are released into the atmosphere, with a high level of carbon particles $(\mathrm{CO} 2)$. The immediate consequence is the increase in global temperature.

The data are presented very eloquently by the World Meteorological Organization [1]. Their opinion, based on synthesizing existing data and simulating some models, is that global warming will continue and will produce effects.

In this context, construction materials and construction solutions must be adapted in the sense of lower energy consumption for their manufacture together with the control of the parameters so that they correspond to the new conditions of operation on site and obviously maintaining an optimal price.

\section{INTERNATIONAL AND NATIONAL CONTEXT FOR REGULATING THE EFFECTS OF CLIMATE CHANGE}

The specialized literature records in 1972, the first important and relevant documents that refer to climate change. It happens after the World Summit in Rio de Janeiro, the Earth 
Summit. Five years later, another important document is drafted - the Kyoto Protocol - which refers to objectives to be achieved and the commitments of the signatory states regarding climate change and the limitation of global warming along with the effects it produces.

In 2015, at the Nations' conference in Paris, the International Climate Agreement was signed, which spoke in its pages of the need to limit global warming.

The activity continued this year, in Glasgow, at the United Nations Conference on the Climate Change - COP26, which took place between October 31, 2021 and November 13, 2021, the signatory parties to the Paris Agreement proposed clear objectives to be achieved regarding the financial contribution and policies applied in each EU country, in order to reduce gas emissions of at least $55 \%$ by 2030 and to maintain global warming below $1,5^{\circ} \mathrm{C}$. It was also on the same occasion that the World Commitment on Methane was adopted. The long-term vision is about achieving the goal, that by 2050 Europe will become climate neutral. [https://www.consilium.europa.eu/ro/policies/climate-change/]

It is obvious that these European policies will influence economic development, markets and jobs, and the production of the building materials industry is also affected. In these conditions, the sustainable materials will be the ones that will remain in the production market. In this context, Romania believes that it can develop policies that will lead to the reduction of carbon emissions by $40 \%$ of the current objective - that of reaching net zero emissions by 2050.[3]

In Romania, the competent authority to manage and implement the EU policies in this field is the Ministry of Environment. It is the central public authority responsible for the overall coordination of climate change adaptation and mitigation policies, strategy and actions. The Ministry of Environment is also the coordinator of the National Commission for Climate Change (NCCC). The National Climate Change Commission (NCCC) is a major inter-ministerial coordinating entity for climate change. [4]

The Ministry of Environment officially presents the National Greenhouse Gas Inventory (NGEI) to the UNFCCC Secretariat, the European

Commissions and the European Environment Agency, taking into account the specific deadlines. [4]

In order to achieve these desiderata, both the existing constructions and the new constructions that will be designed, must provide energy savings, and at the same time the energy losses must tend to zero. In this context, the materials used are also crucial.

\section{PRESENTATION OF THE PASSIVE HOUSE CONCEPT AND ITS LINK TO CLIMATE CHANGE}

The concept of 'passive house' it was first mentioned in 1996 with the founding of the Passive House Institute (PHI), an institute that took up the need to develop an energy efficient and cost-effective house for the large mass of inhabitants in the territory. The first pilot project of this type was developed in Darmstadt, Germany, in 1990 - multi-family housing, where several ideas were experimented with, studied and developed by the researchers of this institute. [5]

The Passive House concept, according to PHI, is based on optimizing relevant building requirements so that heat losses are towards zero and conventional heating and cooling systems are not needed. These requirements must be met under the conditions of ensuring comfort and air ventilation requirements for maintaining healthy living conditions as defined in ISO 7730:2005 - "Ergonomics of the thermal environment - Analytical 
determination and interpretation of thermal comfort using calculation of the PMV and PPD indices and local thermal comfort criteria".

The German passive house standard defines criteria that must be met by building to be included in this category.

These criteria [6] refer to:

- maximum annual consumption of $15 \mathrm{kWh} /$ square metre, for the useful space used

- ensuring, with the help of equipment, adequate air humidity, depending on the climatic region where the building exists

- annual electricity consumption for all domestic equipment (heating, ventilation, domestic hot water production) not to exceed $120 \mathrm{kWh} / \mathrm{m} 2$ of usable floor area

- maximum 0,6 air changes/hour, at a pressure of 50 Pascal, provided that the ISO 7730:2005 standard is met in order to ensure thermal comfort conditions, i.e., a limited period of time with temperature above $25 \square$ Celsius.

In order to meet these desires, the design engineer will have to find the optimal solution for the building envelope. In this sense, the enclosures for the exterior walls will be made of thermally efficient and continuous or compatible materials in order to eliminate thermal bridges that may occur when combining two different materials. Also, the openings for windows and doors will be solved with low-E (low emission) windows.

The ventilation system - heating and cooling - will be designed and incorporated into the building, from the design stage of the installations, taking into account the possibility of recirculation of indoor air.

Global climate change is affecting the Black Sea and as a consequence the coastal microclimate. The temperature of the Black Sea water is on an upward trend, according to official data published by the Grigore Antipa Marine Research Institute, Constanta, Romania, averaging 2-3 degrees Celsius above the average air temperature. Another parameter whose dynamics are changing is the level of the Black Sea [7]. In addition to this, the wind is almost permanently present in the sea area. These parameters influence the entire coastal microclimate and have consequences on the building materials used for a construction thus fulfilling the criteria of the passive house concept

\section{CONSTRUCTION SOLUTIONS FOR BUILDINGS IN COASTAL CLIMATES}

It is a known fact that the building envelope is formed by the perimeter walls of the building, with the purpose of delimiting the exterior climate of the building from the inner one. On site, heat transfer between the inside and the outside of a building takes place through a combination of three transfer pathways, conduction, convection and radiation. [8]

Builduing materials are characterized, in terms of thermal insulation capacity, by three key material parameters:

1. $\boldsymbol{\lambda}$ - the coefficient of thermal conductivity $(\mathrm{W} / \mathrm{mK})$, which represents the amount of heat passing through an element with a surface area of $1 \mathrm{~m} 2$, thickness of $1 \mathrm{~m}$, during one hour, with a difference in temperature between the two surfaces of $1 \mathrm{~K}$ (or $1{ }^{\circ} \mathrm{C}$ )[9];

This parameter varies directly proportional to the density and humidity of the material. Experimentally, it has been shown that a material is a better thermal insulator the lower its thermal conductivity and the drier it is, in a steady state (other parameters are constant).

2. $\mathbf{R}$ - heat transfer resistance, in steady state, by conduction, as per [10]

$$
\mathbf{R}=\boldsymbol{\Sigma}(\mathbf{d} / \lambda)\left[\mathrm{m}^{2} \mathrm{k} / \mathrm{W}\right]
$$


3. $\mathbf{R}_{\mathbf{0}}-$ global thermal resistance, $\left[\mathrm{m}^{2} \mathrm{k} / \mathrm{W}\right]$, for global heat transfer, over the thickness of the element, by conduction, as well as at the external surface of the element (Rse) and the internal surface of the element (Rsi) by convection and radiation [10]:

$R o=R \operatorname{si}+\Sigma(\mathrm{d} / \lambda)+\operatorname{Rse}\left[\mathrm{m}^{2} \mathrm{k} / \mathrm{W}\right]$

On their basis, the corrected thermal resistance is calculated , using the correction coefficients defined in the $\mathrm{C} 107-3 / 2005$ and $\mathrm{C} 107-5 / 2005$ regulations, in order to ensure an indoor climate that corresponds to the passive house concept.

$\mathrm{PhD}$ Prof. Eng. Florin Iordache, considers the building as a thermal system, with two significant components, these being the exterior massiveness (the building envelope) and the interior massiveness (the floor slabs that separate the levels from each other and the interior walls). [11]

From this point of view, it is necessary to have both interior and exterior building materials that are compatible with each other and allowing the building to breathe, while not introducing thermal points at the junction.

Two main groups of building materials are thus identified, leading to the qualification of a building as a passive house: materials for the walls and materials for the general thermal insulation.

An example of a wall model is the vacuum insulating wall (VIP), made of solid wood or prefabricated, organized as a modular system with interlocking elements, Steko type.[12]

\section{Vertical section example}
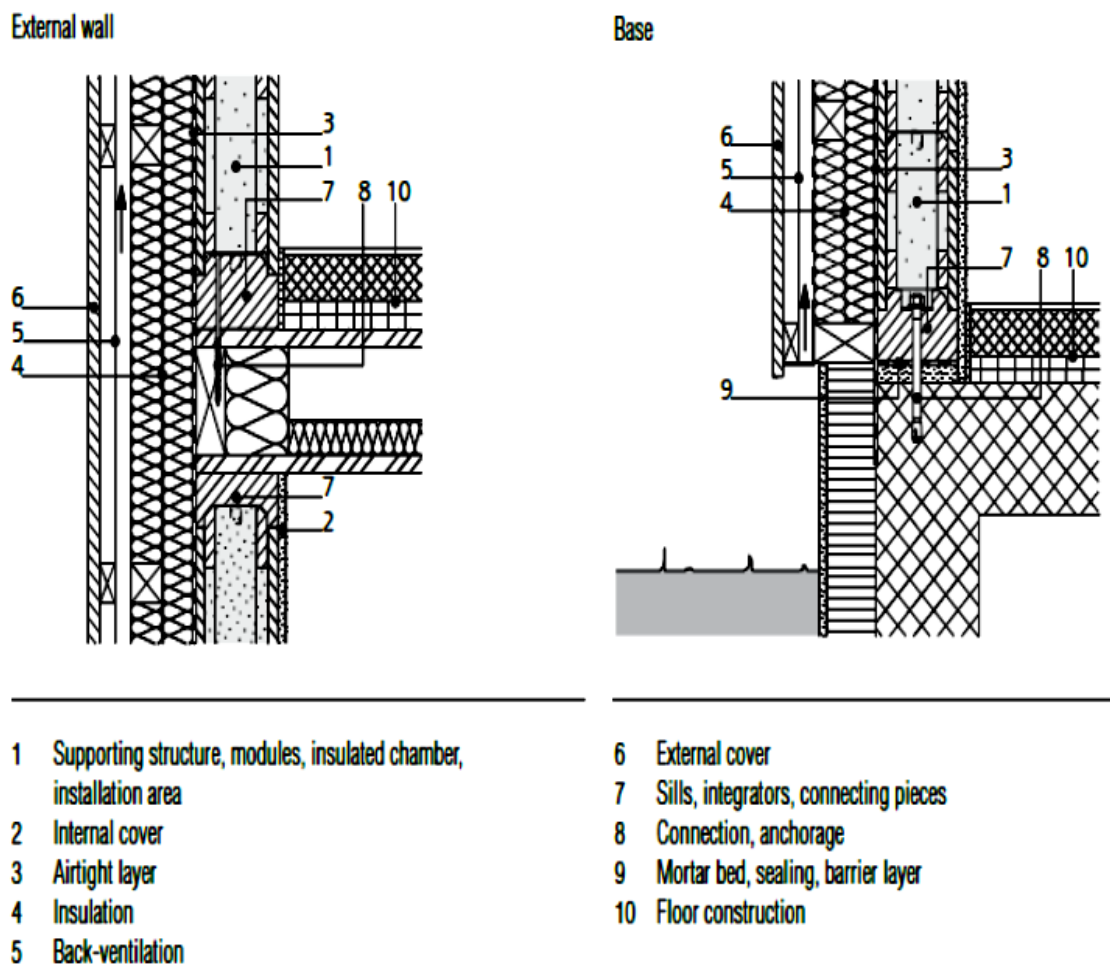

Fig.1 Thermal insulation solution with Steko type modules [12] 
This system, completely industrialized, made out of composite wood or solid wood, presents mechanical characteristics with high values, suitable in Romania in protected areas - natural sites such as the Danube Delta - where not any type of material can be used. Due to the robustness of the interlocking blocks, the usual pipes can be integrated directly into the system. Once assembled, the walls are insulated with a layer of cellulose, with a thickness varying between $12 \mathrm{~cm}$ and $15 \mathrm{~cm}$. The panels must be protected against mechanical degradation to prevent the loss of vacuum. For this reason they are designed as a sandwich panel, with a multi-layer, water vapor proof and gas tight barrier.

Another construction system consists of building the walls with the ecological bricks shown in Fig. 2, type ISOSPAN, made out of wood chips mixed with cement and other mineral binders and synthetic resin in well established proportions, [13].

In the same category are also included Thermibloc ecological brick, [14], which recycles wood chips $-80 \%$ of which are used - and mixes them with a mineralized composition and a synthetic resin binder (Fig. 3).

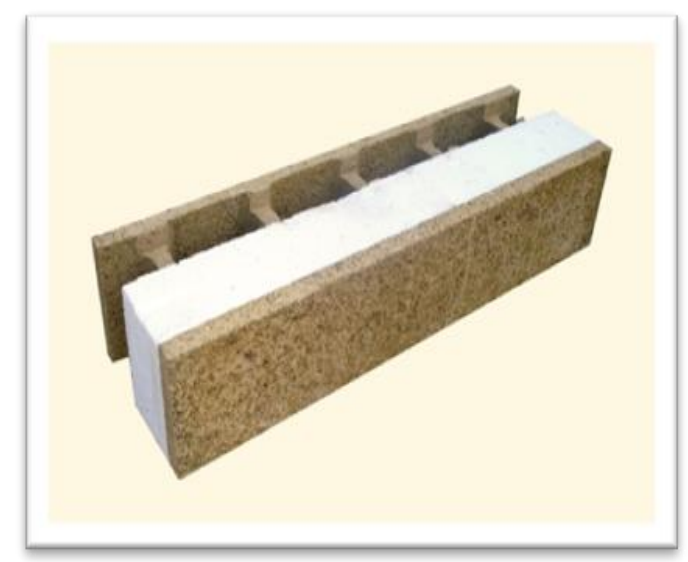

Fig. 2 Standard element type ISOSPAN [13]

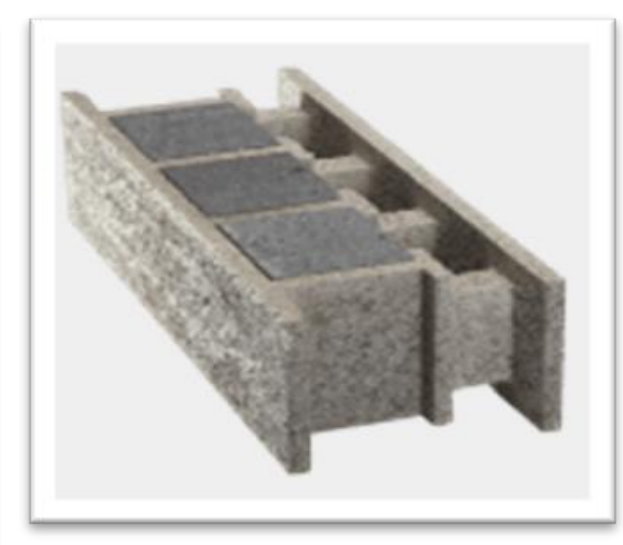

Fig. 3 Standard element Thermibloc [14]

Both building elements are of formwork type with thermal insulation included. The interior can be fitted and reinforced monolithically, or the usual pipes can be inserted. The ISOSPAN ceramic block also contains integrated fireproof or graphite polystyrene. In the Thermibloc ceramic block, either graphite polystyrene or mineral wool is inserted.

Another insulation solution, to meet the passive house criteria, refers to the use of polyurethane foams, fulfilling also the function of waterproofing. Polyurethane foam is composed of polyol and isocynate which, when combined, produce an exothermic reaction and increase their volume. It also increases the volume, with the consequence of filling all voids (free spaces). Isoterm foam [15] has a low technical weight compared to the values of its mechanical parameters and is non-flammable - specific to all synthetic resins.

\section{CONCLUSIONS}

The criteria applicable to the passive house concept differs from one building to another depending on the climate in the area and the climatic changes that are expected to occur. The materials and construction solutions presented can be adapted to almost any climate zone, including variations in mininum and maximum temperatures or the amount of 
precipitation that may change over time. The extreme phenomena that have occured recently in Romania can be ameliorated to the point of not modifying the interior climate of the building by adapting these constructive solutions.

The general designer, for each individual case, will have to approach from the outset, a unified thinking and determine wether to design a passive house that will achieve all the criteria in this matter or a house that will achieve other criteria of energy efficiency and use of energy sources.

\section{REFERENCES}

[1] https://public.wmo.int/en/media/press-release/greenhouse-gas-concentrations

[2] https://www.consilium.europa.eu/ro/policies/climate-change/

[3] https://ccpi.org/download/the-climate-change-performance-index-2021/

[4] http://www.mmediu.ro/

[5] https://passivehouse.com/

[6] https://passivehouse-international.org

[7] http://www.rmri.ro

[8] Normativul C107-2005

[9] Standardul C107/3 - 2005 - Normativ privind calculul termotehnic al elementelor de constructie

[10] Ştefănescu, Dan - Manual de proiectare higrotermică a clădirilor - Iaşi, Editura Societăţii Academice "Matei - Teiu Botez", 2012

[11] Florin Iordache - UTCB - Comportamentul termic dinamic al unei cladiri, ed Matrixrom, 2015

[12] https://www.steko.ch

[13] https://eco-domo.ro/caramizi-ecologice/

[14] https://www.thermibloc.fr/produits

[15] [https://isoterm.ro/

Note:

Gabriela Draghici - Ovidius University of Constanta, Bd. Mamaia nr. 124, 900356-Constanta, Romania (corresponding author to provide phone: +40-241-619040; fax: +40-241-618372; e-mail: draghici.gabriela@univ-ovidius.ro)

Cosmin Filip - Ovidius University of Constanta, Bd. Mamaia nr. 124, 900356-Constanta, Romania (e-mail: filip.cosmin@univ-ovidius.ro)

Alexandru Nicolae Bizu- PhD, Gh. Asachi Technical University of Iasi, Str. Prof. dr. docent Dimitrie Mangeron, nr. 67, corp T, Romania (e-mail: bizu.alexandru@gmail.com) 